\title{
CLINICAL AND HEMATOLOGICAL ALTERATIONS IN DOGS DURING EXPERIMENTAL ENVENOMATION WITH Crotalus durissus terrificus VENOM AND TREATED WITH ANTIOPHIDIC SERUM
}

\author{
NOGUEIRA R. M. B (1), SAKATE M. (2)
}

(1) Department of Small Animals, Medical Clinic, UNOESTE, Presidente Prudente, São Paulo State, Brazil; (2) Department of Small Animals, Medical Clinic, School of Veterinary Medicine and Animal Husbandry, São Paulo State University, UNESP, Botucatu, São Paulo State, Brazil.

ABSTRACT: The present work aimed to evaluate the clinical and hematological aspects during experimental envenomation by Crotalus durissus terrificus in dogs treated with different antiophidic serum doses. Sixteen dogs were divided into two groups of eight animals each. Group I received $1 \mathrm{mg} / \mathrm{kg}$ venom subcutaneously and $30 \mathrm{mg}$ antiophidic serum intravenously; Group II received $1 \mathrm{mg} / \mathrm{kg}$ venom subcutaneously and 60mg antiophidic serum intravenously. In the clinical evaluation, we observed ataxia, moderate sedation, dilated pupils, sialorrhea, flaccid paralysis of mandibular muscles, and discreet edema at the site of venom inoculation. Evaluating red and white blood cells, we observed a decrease of hemoglobins, globular volume and erythrocytes, and an increase of plasmatic proteins, leukocytes, neutrophils, monocytes and lymphocytes. Clotting time increased and there was blood incoagulability with return to normal clotting time six hours after antiophidic serum administration. Animals treated with six antiophidic serum flasks had a faster recovery than the animals that received three serum flasks.

KEY WORDS: Crotalus durissus terrificus, dog, clinical aspects, hematological aspects, venom.

\section{CORRESPONDENCE TO:}

ROSA MARIA BARILLI NOGUEIRA, Rua Neida Rodriguez de Paula, 214, 19025120, Presidente Prudente, São Paulo, Brasil. Email: noballi@ig.com.br. 
R. M. B. Nogueira and M. Sakate. CLINICAL AND HEMATOLOGICAL ALTERATIONS IN DOGS DURING EXPERIMENTAL ENVENOMATION WITH Crotalus durissus terrificus VENOM AND TREATED WITH ANTIOPHIDIC SERUM. J. Venom. Anim. Toxins incl. Trop. Dis., 2006, 12, 2, p.286

\section{INTRODUCTION}

In Brazil, the genus Crotalus is considered of great importance due to the severe clinical aspects it provokes in humans and animals, and most of the time these can be fatal when treatment with specific serum is not quickly instituted (4). Crotalus snakes are considered more venomous than the snakes of the Bothrops genus (10). Crotalus venom is constituted of several fractions and this division reveals the following toxins: crotoxin, crotamine, giroxin, and convulxin $(9,20,21,22)$. Crotalic venom has three main actions: neurotoxic (12), myotoxic $(5,6)$, and hemolytic (23). The major complication observed in Crotalus accidents is the development of acute renal insufficiency with tubular necrosis $(17,23)$.

\section{MATERIAL AND METHODS}

This experiment was approved by the Ethics Committee of University of Western São Paulo, UNOESTE, Presidente Prudente, São Paulo, Brazil.

We used sixteen dogs (eight females and eight males) between 1 and 4 years old, without a defined breed, weight varying from 6 to $15 \mathrm{~kg}$, from the Central Kennel of UNOESTE. By a complete physical exam and laboratory tests, animals that presented normal values were selected (18). They were kept in individual stalls in the kennel of the Veterinary Hospital of UNOESTE with water and food ad libitum.

The antiophidic serum (bothropic-crotalic) used was from Vencofarma Laboratory (serum sample 001/03); each flask of $10 \mathrm{ml}$ serum neutralizes $10 \mathrm{mg}$ crotalic venom.

Animals were divided into two groups with eight animals in each group, four females and four males, being Group I: animals inoculated with crotalic venom and treated with 30mg of antiophidic serum six hours after venom administration; and Group II: animals inoculated with crotalic venom and treated with $60 \mathrm{mg}$ of antiophidic serum six hours after venom administration.

Lyophilized crotalic venom donated from the Center for the Study of Venoms and Venomous Animals, CEVAP, UNESP, Brazil, was reconstituted in sterile saline solution and subcutaneously inoculated, at the dose of $1 \mathrm{mg} / \mathrm{kg}$ live weight, into the animals' thigh lateral face; antiophidic serum was intravenously administered six hours after venom inoculation. 
R. M. B. Nogueira and M. Sakate. CLINICAL AND HEMATOLOGICAL ALTERATIONS IN DOGS DURING EXPERIMENTAL ENVENOMATION WITH Crotalus durissus terrificus VENOM AND TREATED WITH ANTIOPHIDIC SERUM. J. Venom. Anim. Toxins incl. Trop. Dis., 2006, 12, 2, p.287

\section{Clinical evaluation}

The following measurements: temperature, heart and breathing rate, pulse, pupil diameter, ataxia, sedation, and sialorrhea were obtained at different moments (Table 1).

\section{Blood cell count}

Blood samples were collected by the jugular vein puncture using a hypodermic needle (30x08mm) and a syringe of $20 \mathrm{ml}$; later, red blood cells and white blood cells were counted at different moments (Table 1).

\section{Clotting Time}

Clotting time was evaluated at different moments by the Lee \& White method [Table 1] (16).

\section{Statistical Analysis}

Each variable was studied by using multivariate analysis, which allowed the comparison between groups at every moment as well as between moments of evaluation for each group.

For the variables whose evaluations were given by scores, groups were compared at every moment using the Kruskal-Wallis non-parametric test, and the effect of the moments on each group was compared by the Friedman non-parametric test (19, 28). A significance level of $p<0.05$ was adopted.

\section{RESULTS AND DISCUSSION}

\section{Clinical Evaluation}

Discreet edema was observed at the site of inoculation of crotalic venom (CV) in the animals of Groups I and II, which is in agreement with the data available in literature $(7,11)$.

Widespread muscular pain of moderate intensity was observed from 6 to 48 hours after venom inoculation and 42 hours after antiophidic serum administration on Groups I and II. Pain was evaluated by observing the dogs and graduated according to intensity ( 0 = no pain; 1 = light pain; 2 = moderate pain; 3 = serious pain).

Animals of Groups I and II presented ataxia and light sedation at M1 (4h after venom administration - AV) compared to the control moment (M0). This effect is resulting 
R. M. B. Nogueira and M. Sakate. CLINICAL AND HEMATOLOGICAL ALTERATIONS IN DOGS DURING EXPERIMENTAL ENVENOMATION WITH Crotalus durissus terrificus VENOM AND TREATED WITH ANTIOPHIDIC SERUM. J. Venom. Anim. Toxins incl. Trop. Dis., 2006, 12, 2, p.288

from the CV action on the central and peripheral nervous systems $(15,25,26)$. The animals were in lateral decubitus with moderate sedation 8 hours after $\mathrm{CV}$ inoculation and two hours after antiophidic serum administration and persisted until 24 hours AV and 18 hours after antiophidic serum administration with recovery beginning at M4 (48h AV) and completed at M6 (144h AV).

At M5 (72h AV), animals of Group II showed a faster recovery in relation to decubitus, ataxia and sedation, probably because they received a larger amount of antiophidic serum (60mg) compared to those of Group I, which received 30mg of the serum.

Evaluation of the temperature did not show any significant difference between moments for each group nor between groups for every moment. There was a decrease in the heart frequency of the animals of both groups at M1, although the values showed to be normal for this species. No alteration was observed in the pulse evaluation of the groups.

Regarding the breathing frequency, we observed just a small decrease in the animals of Group II at moments M1 and M2 (8h AV) compared to the other moments, and any significant alteration was verified compared to Group I.

Breathing alteration together with dyspnea, tachypnea, and acute breathing insufficiency was also mentioned by Amaral et al. (2) in three human patients victims of accident by Crotalus durissus terrificus. Signs appeared in the first 48 hours after the ophidic accident but the patients did not present alterations in radiographs of the thorax. In spite of the absence of significant breathing alterations in the animals of the present study, it is necessary to emphasize that complications due to paralysis of the breathing musculature are important complications mentioned by other authors $(2,12,17)$.

According to a study with CV on bovine (29), the animals presented alterations in temperature parameters, and heart and breathing frequencies; however, these data are not pathognomonic to differentiate crotalic envenoming from another envenoming, for example bothropic.

Pupil diameter, normal at M0, started to become mydriatic from M1 to M5 in Group I and from M1 to M4 in Group II. Mydriasis occurred, being bilaterally responsive to light at all the moments studied (25). The pupil diameter in Group II returned to normality earlier than in Group I, probably due to a larger amount of antiophidic serum received by the former. 
R. M. B. Nogueira and M. Sakate. CLINICAL AND HEMATOLOGICAL ALTERATIONS IN DOGS DURING EXPERIMENTAL ENVENOMATION WITH Crotalus durissus terrificus VENOM AND TREATED WITH ANTIOPHIDIC SERUM. J. Venom. Anim. Toxins incl. Trop. Dis., 2006, 12, 2, p.289

During the clinical evaluation, we noticed a discreet to moderate sialorrhea in the dogs of Group I from M1 to M3 (24h AV) and in those of Group II between M1 and M2. Again it was observed that Group II, probably as a result of the larger amount of antiophidic serum received (6 flasks), returned to normality in a smaller amount of time compared to Group I.

Besides sialorrhea clinical aspects, the animals of both groups used to stay with the mouth open, showing deglutition difficulty from M1 (4h AV) to M3 due to flaccid paralysis of the mandibular muscles. We observed vomit in five animals, three from Group I and two from Group II. Sialorrhea occurred due to the action of the venom neurotoxic fraction, a crotoxin that causes paralysis, similar to the effects caused by curare. Its main effect is neuromuscular transmission blockade, suggesting that paralysis and breathing alterations were due to the neuromuscular junction blockade (2). This fact allows for the conclusion that this neurotoxin acts in the presinaptic parasympathetic nerves, inhibiting acetylcholine release $(2,7)$.

According to Hudelson \& Hudelson (13), vomit signs, salivation, defecation, and increase of the urinary frequency are linked to the autonomic nervous system involvement, however without confirmation.

\section{Blood Cell Count}

As for the number of red blood cells, a significant decrease was observed $(p<0.05)$ in Group II at M3 (72h AV) and M4 (144h AV) when compared to the control moment (M0), and a fast decrease was seen at M2 (24h AV) in relation to M0. In Group I, there was a fast decrease $(p>0.05)$ of this parameter starting from M2 (Table 2).

Mean values of hemoglobin concentration and globular volume presented a significant fall $(p<0.05)$ in relation to the control moment in dogs of Groups I and II, starting from M2 until M4 (Table 2).

Decrease of the variables erythrocyte, hemoglobin and globular volume can be attributed to the venom hemolytic action verified in vitro (25). Alteration in the serum coloration in blood samples collected from all the animals of Groups I and II six hours after venom inoculation was interpreted as hemolysis [Table 2] (27).

Increase of total plasmatic protein (TPP) was verified $(p<0.05)$ for Group I at M3 in relation to the other moments. At that moment (M3), the protein plasmatic level in this group showed higher increase compared to Group II (Table 2). The high level of TPP can be explained by the clinical aspects of dehydration and the shock the animals 
R. M. B. Nogueira and M. Sakate. CLINICAL AND HEMATOLOGICAL ALTERATIONS IN DOGS DURING EXPERIMENTAL ENVENOMATION WITH Crotalus durissus terrificus VENOM AND TREATED WITH ANTIOPHIDIC SERUM. J. Venom. Anim. Toxins incl. Trop. Dis., 2006, 12, 2, p.290

developed after CV inoculation (14), and also by the fact that the animals of Group II received a higher dose (60mg) of antiophidic serum. Differences were not observed in fibrinogen values in the comparison between groups at every moment and in the comparison between moments for each group. Studies have shown that the venom causes hypofibrinogenemia $(1,3,15,30)$; therefore, the non-alteration of the fibrinogen values might have been due to the technique used.

White blood cells from the animals of both groups showed leukocytosis with neutrophilia 24 hours after CV inoculation and 18 hours after serotherapy, returning to normal values in the subsequent moment (Table 3).

The monocytes number increased significantly at M3 in both groups, compared to the other moments; as for the number of lymphocytes, a decrease was observed in Groups I and II at M1 (6h AV) and M2 in relation to the control moment. Regarding eosinophil values, there was a decrease at M2 compared to M0 in Group I. In Group II, values remained close to those of $\mathrm{MO}$ (Table 3 ).

Leukocytosis with neutrophilia can be due to interaction between CV and the animal organism, inducing a typical acute-phase response with release of catecholamines, cellular mediators and humor, besides serum chemotactic factors (7). Other possibility for leukocytic response would be the stress induced by pain, manipulation and discomfort of the animals leading to leukocytosis with neutrophilia, monocytosis, lymphopenia, and eosinopenia (14).

Clinical aspects of leukocytosis with a left shift displayed in the present study have been referred in the initial phase of crotalic envenoming in patients treated with specific serum (24). Jorge \& Ribeiro (15) also verified leukocytosis aspects in eight patients bitten by rattlesnake, and six of them showed left shift, a response similar to that of one of the dogs in this study. Another report by Barraviera et al. (8) displays an elevation in the number of leukocytes and segmented neutrophils in crotalic accident with humans.

\section{Clotting Time}

Evaluation of the clotting time showed a significant alteration from M1 (6h AV) for Groups I and II. The animals presented blood incoagulability six hours after CV inoculation. Six hours after the antiophidic serum administration, the clotting time returned to normality, and for Group I this return was more precocious than for Group II (Table 4). Alteration in the clotting time is due to the fraction named "thrombin-like", 
R. M. B. Nogueira and M. Sakate. CLINICAL AND HEMATOLOGICAL ALTERATIONS IN DOGS DURING EXPERIMENTAL ENVENOMATION WITH Crotalus durissus terrificus VENOM AND TREATED WITH ANTIOPHIDIC SERUM. J. Venom. Anim. Toxins incl. Trop. Dis., 2006, 12, 2, p.291

capable of converting fibrinogen in fibrin, leading the patient to afibrinogenemia, which culminates with the prolonging of the clotting time $(1,3,16,30)$.

Table 1: Moments of evaluation of the clinical evolution, blood count and clotting time.

\begin{tabular}{|c|c|c|c|c|c|c|c|c|}
\hline \multirow{2}{*}{$\begin{array}{c}\text { Clinical evaluation } \\
\text { Blood count }\end{array}$} & Control & 4h AV & 8h AV & 24h AV & 48h AV & 72h AV & 144hAV \\
\hline Clotting time & Control & $6 \mathrm{~h} \mathrm{AV}$ & $24 \mathrm{~h} \mathrm{AV}$ & $72 \mathrm{~h} \mathrm{AV}$ & $144 \mathrm{hAV}$ & - & - \\
\hline
\end{tabular}

$\mathrm{AV}=$ after venom; $\mathrm{h}=$ hours. Antiophidic serum was administered $6 \mathrm{~h}$ after venom inoculation.

Table 2: Means of red blood cell count according to groups and moments.

\begin{tabular}{|c|c|c|c|c|c|}
\hline \multirow[b]{2}{*}{ GROUPS } & \multicolumn{4}{|c|}{ MOMENTS } & \multirow[b]{2}{*}{ M4 } \\
\hline & MO & M1 & M & M3 & \\
\hline \multicolumn{6}{|c|}{ Red blood cells $\left(\times 10^{6} / \mu \mathrm{l}\right)$} \\
\hline $\mathbf{I}$ & 6,354 & $6,351 \mathrm{Aa}$ & $5,896 \mathrm{Aa}$ & $5,961 \mathrm{Aa}$ & 5,634Aab \\
\hline II & 6,421 & $6,611 \mathrm{Aa}$ & $6.288 \mathrm{Aa}$ & $5,448 \mathrm{Ba}$ & $4,889 \mathrm{Ca}$ \\
\hline \multicolumn{6}{|c|}{ Hemoglobin (g/dl) } \\
\hline $\mathbf{I}$ & 15.04 & $15.57 \mathrm{Aa}$ & $14.42 \mathrm{ACa}$ & $13.67 \mathrm{BCa}$ & $12.58 \mathrm{Ba}$ \\
\hline II & 15.72 & $16.66 \mathrm{Aa}$ & $15.17 \mathrm{Ba}$ & $13.75 \mathrm{Ca}$ & $12.28 \mathrm{Da}$ \\
\hline \multicolumn{6}{|c|}{ Globular volume (\%) } \\
\hline $\mathbf{I}$ & 44.87 & 47.00Aa & $43.25 \mathrm{Ba}$ & $40.37 \mathrm{BCa}$ & $38.12 \mathrm{Cab}$ \\
\hline II & 46.12 & 49.75Aa & $45.12 \mathrm{Ba}$ & $41.12 \mathrm{Ca}$ & 36.37Da \\
\hline \multicolumn{6}{|c|}{ Total plasmatic protein (g/dl) } \\
\hline $\mathbf{I}$ & 7.30 & $7.12 \mathrm{Aa}$ & $7.02 \mathrm{Aa}$ & $7.67 \mathrm{Ba}$ & $6.97 \mathrm{Aa}$ \\
\hline II & 6.97 & $7.02 \mathrm{Aa}$ & 6.95Aa & 7.00Aab & $6.67 \mathrm{Aa}$ \\
\hline
\end{tabular}

Capital letters compare moments in each group. Lowercase letters compare groups at every moment. Means followed by the same letters do not differ significantly $(p>0.05)$. 
R. M. B. Nogueira and M. Sakate. CLINICAL AND HEMATOLOGICAL ALTERATIONS IN DOGS DURING EXPERIMENTAL ENVENOMATION WITH Crotalus durissus terrificus VENOM AND TREATED WITH ANTIOPHIDIC SERUM. J. Venom. Anim. Toxins incl. Trop. Dis., 2006, 12, 2, p.292

Table 3: Means of white blood cell count according to groups and moments.

\begin{tabular}{|c|c|c|c|c|c|}
\hline \multirow[b]{2}{*}{ GROUPS } & \multicolumn{4}{|c|}{ MOMENTS } & \multirow[b]{2}{*}{ M4 } \\
\hline & MO & M1 & M2 & M3 & \\
\hline \multicolumn{6}{|c|}{ Leucocytes $/ \mu \mathrm{I}$} \\
\hline $\mathbf{I}$ & 11,950 & $16,350 \mathrm{Aa}$ & $19,075 \mathrm{Aa}$ & $15,920 \mathrm{Aa}$ & $14,681 \mathrm{Aa}$ \\
\hline II & 10,610 & $13,470 \mathrm{Aa}$ & $20,700 \mathrm{Bb}$ & $14,910 \mathrm{Aa}$ & $12,410 \mathrm{Aa}$ \\
\hline \multicolumn{6}{|c|}{ Segmented neutrophils (\%) } \\
\hline $\mathbf{I}$ & 7,417 & $12,973 \mathrm{Aa}$ & $16,822 \mathrm{Ba}$ & $11,351 \mathrm{Aa}$ & $9,404 \mathrm{Aa}$ \\
\hline II & 6,045 & $11,611 \mathrm{Aa}$ & $19,017 \mathrm{Ba}$ & $9,204 \mathrm{Aa}$ & $9,033 \mathrm{Aa}$ \\
\hline \multicolumn{6}{|c|}{ Monocytes (\%) } \\
\hline I & 496 & 780Aa & 391Aa & $1,376 \mathrm{Ba}$ & 888Aa \\
\hline II & 532 & $367 \mathrm{Aa}$ & $1026 \mathrm{Aa}$ & 1135Bab & $745 \mathrm{Aa}$ \\
\hline \multicolumn{6}{|c|}{ Lymphocytes (\%) } \\
\hline $\mathbf{I}$ & 2,635 & $1,793 \mathrm{ABa}$ & $1,269 \mathrm{Aa}$ & $2,335 \mathrm{Ba}$ & $2,292 \mathrm{Ba}$ \\
\hline II & 2,600 & $1,849 \mathrm{Aa}$ & 1,654Aab & $2,529 \mathrm{Aa}$ & $2,382 \mathrm{Aa}$ \\
\hline \multicolumn{6}{|c|}{ Eosinophils $(\mu \mathrm{l})$} \\
\hline $\mathbf{I}$ & $\begin{array}{c}1007 \mathrm{Aa} \\
(668 ; 2366)\end{array}$ & $\begin{array}{c}701 \mathrm{Aa} \\
(408 ; 1281)\end{array}$ & $\begin{array}{c}204 \mathrm{Ba} \\
(144 ; 297)\end{array}$ & $\begin{array}{c}\text { 473Aa } \\
(348 ; 1120)\end{array}$ & $\begin{array}{c}1149 \mathrm{Aa} \\
(651 ; 1450)\end{array}$ \\
\hline II & $\begin{array}{c}515 A a \\
(350 ; 759)\end{array}$ & $\begin{array}{c}290 A b \\
(158 ; 327)\end{array}$ & $\begin{array}{l}\mathrm{OAa} \\
(0 ; 0)\end{array}$ & $\begin{array}{c}\text { 328Aa } \\
(97 ; 561)\end{array}$ & $\begin{array}{c}\text { 341Ab } \\
(165 ; 443)\end{array}$ \\
\hline
\end{tabular}

Capital letters compare moments in each group. Lowercase letters compare groups at every moment. Means followed by the same letters do not differ significantly $(p>0.05)$. 
R. M. B. Nogueira and M. Sakate. CLINICAL AND HEMATOLOGICAL ALTERATIONS IN DOGS DURING EXPERIMENTAL ENVENOMATION WITH Crotalus durissus terrificus VENOM AND TREATED WITH ANTIOPHIDIC SERUM. J. Venom. Anim. Toxins incl. Trop. Dis., 2006, 12, 2, p.293

Table 4: Means of clotting time according to groups and moments.

\begin{tabular}{|ccccccc|}
\hline & \multicolumn{7}{c|}{ MOMENTS } \\
\cline { 2 - 7 } GROUPS & M0 & M1 & M2 & M3 & M4 & M5 \\
\hline & \multicolumn{7}{c|}{ Clotting Time } \\
\hline I & $1.0 \mathrm{Aa}$ & $0.0 \mathrm{Ba}$ & $0.0 \mathrm{Ba}$ & $0.0 \mathrm{Ba}$ & $1.0 \mathrm{Aa}$ & $1.0 \mathrm{Aa}$ \\
& $(1.0 ; 1.0)$ & $(0.0 ; 0.0)$ & $(0.0 ; 0.0)$ & $(0.0 ; 0.0)$ & $(0.0 ; 1.0)$ & $(1.0 ; 1.0)$ \\
\hline II & $1.0 \mathrm{Aa}$ & $0.0 \mathrm{Ba}$ & $0.0 \mathrm{Ba}$ & $0.0 \mathrm{Ba}$ & $0.0 \mathrm{Ba}$ & $1.0 \mathrm{Aa}$ \\
& $(1.0 ; 1.0)$ & $(0.0 ; 0.0)$ & $(0.0 ; 0.0)$ & $(0.0 ; 0.0)$ & $(0.0 ; 0.5)$ & $(1.0 ; 1.0)$ \\
& & & & & & \\
\hline
\end{tabular}

Capital letters compare moments in each group. Lowercase letters compare groups at every moment. Means followed by the same letters do not differ significantly $(p>0.05)$. Score: $0.0=$ not clotted; $1.0=$ clotted.

\section{CONCLUSION}

Results of this experimental study with crotalic venom in dogs show that the venom causes important clinical alterations as ataxia followed by sedation, deglutition difficulty, sialorrhea, midriasis, and muscular pain.

Hematological alterations were characterized mainly by the decrease in the erythrocytes number, hemoglobin and globular volume, and the increase in total plasmatic protein, besides leukocytosis with neutrophilia.

A picture of blood incoagulability was observed six hours after venom inoculation and clotting time returned to normality six hours after antiophidic serum administration. Hemolysis was observed in Groups I and II six hours after venom inoculation. Animals that received a larger amount of serum had a faster recovery.

\section{ACKNOWLEDGEMENTS}

The authors are grateful to the masters program of UNOESTE, for the financial support; to the masters program of FMVZ-UNESP, Botucatu, for the orientation; to Center for the Study of Venoms and Venomous Animals, CEVAP, UNESP, Botucatu; to the Clinical Laboratory, Veterinary Hospital, UNOESTE; and to Dr. Adalberto J. Crocci, for the statistical analysis. 
R. M. B. Nogueira and M. Sakate. CLINICAL AND HEMATOLOGICAL ALTERATIONS IN DOGS DURING EXPERIMENTAL ENVENOMATION WITH Crotalus durissus terrificus VENOM AND TREATED WITH ANTIOPHIDIC SERUM. J. Venom. Anim. Toxins incl. Trop. Dis., 2006, 12, 2, p.294

\section{REFERENCES}

1 AMARAL CFS., DA SILVA OA., LOPEZ M., PEDROSO ER. Afibrinogenemia following snakebite (Crotalus durissus terrificus). Am. J. Trop. Med. Hyg., 1980, 29, 1453-5.

2 AMARAL CFS., MAGALHÃES RA., REZENDE NA. Comprometimento respiratório secundário a acidente ofídico crotálico (Crotalus durissus). Rev. Inst. Med. Trop. São Paulo, 1991, 33, 251-5.

3 AMARAL CFS., REZENDE NA., PEDROSA TMG., DA SILVA OA., PEDROSO ER. Afibrinogenemia secundária a acidente ofídico crotálico (Crotalus durissus terrificus). Rev. Inst. Med. Trop. São Paulo, 1988, 30, 288-92.

4 ARAÚJO P., BELLUOMINI HE. Toxicidade de venenos ofídicos. I. Sensibilidade específica de animais domésticos e de laboratório. Mem. Inst. Butantan, 1960-62, 30, 143-56.

5 AZEVEDO MARQUES MM., CUPO P., COIMBRA TM., HERING SE., ROSSI MA., LAURE CJ. Myonecrosis, myoglobinuria and acute renal failure induced by South American rattlesnake (Crotalus durissus terrificus) envenomation in Brazil. Toxicon, 1985, 23, 631-6.

6 AZEVEDO-MARQUES MM., CUPO P., COIMBRA TM., HERING SE., ROSSI MA., OLIVEIRA JA. Mionecrose e insuficiência renal aguda mioglobinúrica após acidente crotálico. In: CONGRESSO DA SOCIEDADE BRASILEIRA DE MEDICINA TROPICAL, 18, Ribeirão Preto, 1982. Anais... Ribeirão Preto, 1982. p.12.

7 BARRAVIERA B. Acidentes por serpentes dos gêneros Crotalus e Micrurus. In: BARRAVIERA B. Ed. Venenos animais: uma visão integrada. Rio de Janeiro: EPUC, 1994: 281-95.

8 BARRAVIERA B., COELHO KY., CURI PR., MEIRA DA. Liver dysfunction in patients bitten by Crotalus durissus terrificus (Laurenti, 1768) snakes in Botucatu (State of São Paulo, Brazil). Rev. Inst. Med. Trop. São Paulo, 1995, 37, 63-9.

9 BARRIO A. Gyroxin, a new neurotoxin of Crotalus durissus terrificus venom. Acta Physiol. Lat. Am., 1961, 11, 224-32.

10 BELLUOMINI HE. Conhecimentos sobre as serpentes brasileiras e medidas de prevenção de acidentes. Rev. Bras. Saúde Ocup., 1984, 12, 82-96. 
R. M. B. Nogueira and M. Sakate. CLINICAL AND HEMATOLOGICAL ALTERATIONS IN DOGS DURING EXPERIMENTAL ENVENOMATION WITH Crotalus durissus terrificus VENOM AND TREATED WITH ANTIOPHIDIC SERUM. J. Venom. Anim. Toxins incl. Trop. Dis., 2006, 12, 2, p.295

11 BICUDO PL. Acidentes ofídicos em Medicina Veterinária. In: BARRAVIERA B.

Ed. Venenos animais: uma visão integrada. Rio de Janeiro: EPUC, 1994: 375-87.

12 BRAZIL OV., FARINA R., YOSHIDA L., DE OLIVEIRA VA. Pharmacology of crystalline crotoxin. 3. Cardiovascular and respiratory effects of crotoxin and Crotalus durissus terrificus venom. Mem. Inst. Butantan, 1966, 33, 993-1000.

13 HUDELSON S., HUDELSON P. Pathophysiology of snake envenomization and evaluation of treatment - part 2. Comp. Cont. Educ. Pract. Vet., 1995, 17, 1035-40.

14 JAIN NC. Essentials of veterinary hematology. Philadelphia: Lea \& Febiger, 1993. 417p.

15 JORGE MT., RIBEIRO LA. Epidemiologia e quadro clínico do acidente por cascavel sul-americana (Crotalus durissus). Rev. Inst. Med. Trop. São Paulo, 1992, 34, 347-54.

16 LEE RI., WHITE PD. A clinical study of the coagulation time of blood. Am. J. Med. Sci., 1913, 145, 495-503.

17 MAGALHÃES RA., RIBEIRO MMF., REZENDE NA., AMARAL CFS. Rabdomiólise secundária a acidente crotálico (Crotalus durissus terrificus). Rev. Inst. Med. Trop. São Paulo, 1986, 28, 228-33.

18 MCCURNIN DM., POOFFENBARGER EM. Small animal physical diagnosis and clinical procedures. Phyladelphia: Saunders, 1991. 222p.

19 MORRISON DF. Multivariate statistical methods. New York: McGraw-Hill, 1990. 450p.

20 MOURA-GONÇALVES J., VIEIRA LG. Estudos sobre venenos de serpentes brasileiras. I. Análise eletroforética. An. Acad. Bras. Cienc., 1950, 22, $141-$ 50.

21 PRADO-FRANCESCHI J., BRAZIL OV. Convulxin, a new toxin from the venom of the South American rattlesnake Crotalus durissus terrificus. Toxicon, 1981, 19, 875-87.

22 ROODT AR., DOLAB JA., SEGRE L. Fisiopatologia y diagnóstico del ataque por serpientes venenosas. Una breve actualización. Rev. Med. Vet., 1996, 77, 64-71. 
R. M. B. Nogueira and M. Sakate. CLINICAL AND HEMATOLOGICAL ALTERATIONS IN DOGS DURING EXPERIMENTAL ENVENOMATION WITH Crotalus durissus terrificus VENOM AND TREATED WITH ANTIOPHIDIC SERUM. J. Venom. Anim. Toxins incl. Trop. Dis., 2006, 12, 2, p.296

23 ROSENFELD G. Symptomatology, pathology and treatment of snake bites in South America. In: BUCHERL W., BUCKLEY EE. Eds. Venomous animals and their venoms. New York: Academic Press, 1971: 345-84.

24 ROSENFELD G. Acidentes por animais peçonhentos: serpentes, aranhas, escorpiões. In: VERONESI R. Ed. Doenças infecciosas e parasitárias. 8.ed. Rio de Janeiro: Guanabara Koogan, 1991: 951-62.

25 ROSENFELD G., KELEN EMA., NUDEL F. Hemolytic activity of animal venoms. I. Classification in different types and activities. Mem. Inst. Butantan., 196062, 30, 103-16.

26 SALIBA AM., BELLUOMINI HE., LEINZ FF. Pathology of experimental poisoning of cattle with Crotalus snake venom. Dtsch. Tierarztl. Wochenschr., 1983, 5, 513-7.

27 SANO-MARTINS IS., SANTORO ML., MORENA P., SOUSA-E-SILVA MC., TOMY SC., ANTONIO LC., ISHIKAWA AK., GONÇALVES IL., LARSSON MH., HAGIWARA MK. Hematological changes induced by Bothrops jararaca venom in dogs. Braz. J. Med. Biol. Res, 1995, 28, 303-12.

28 SIEGEL S. Estatística não paramétrica para as ciências do comportamento. São Paulo: McGraw-Hill, 1975. 350p.

29 SOERENSEN B., NETO LZ., OLIVEIRA AM., SANTOS RV., MESSIAS CV. Aspecto clínico e laboratorial do envenenamento botrópico e crotálico em bovinos. Unimar Ciênc., 1995, 4, 28-33.

30 THOMAZINI IA., BARRAVIERA B. Alterações hematológicas nos acidentes por animais peçonhentos. In: BARRAVIERA B. Ed. Venenos animais: uma visão integrada. Rio de Janeiro: EPUC, 1994: 81-96. 